Supporting Information

\title{
Diffusion control in single-site zinc reticular amination catalysts
}

Francisco G Cirujano $^{\text {a* }}$, Elena López-Maya ${ }^{a}$, Neyvis Almora-Barrios ${ }^{\mathrm{a}}$ Ana Rubio-Gaspar ${ }^{\mathrm{a}}$, Nuria Martín $^{\mathrm{a}}$, Jorge A. R. Navarro ${ }^{\mathrm{b}}$ and Carlos Martí-Gastaldo ${ }^{\mathrm{a} *}$

${ }^{a}$ Instituto de Ciencia Molecular (ICMol), Universitat de Valencia, Catedrático José Beltrán Martínez $n^{\circ}$ 2, 46980 Paterna, Valencia, Spain

${ }^{b}$ Department of Inorganic Chemistry, University of Granada, Avenida de Fuente Nueva, s/n, 18071 Granada, Spain

* francisco.c.garcia@uv.es

* carlos.marti@uv.es 


\section{TABLE OF CONTENTS}

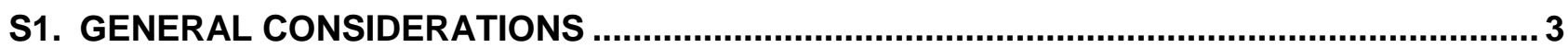

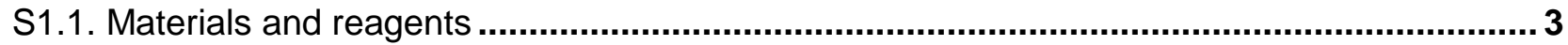

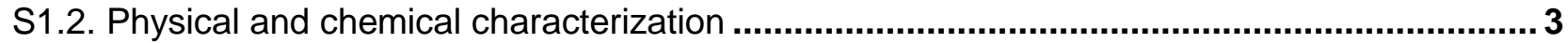

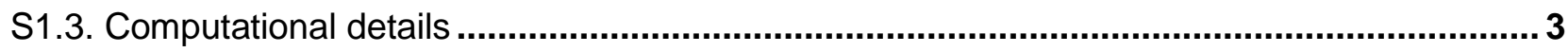

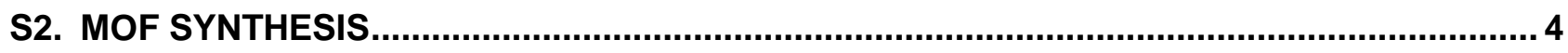

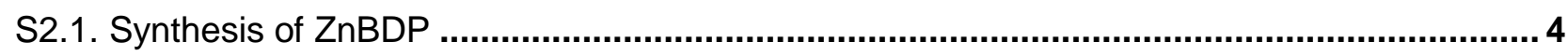

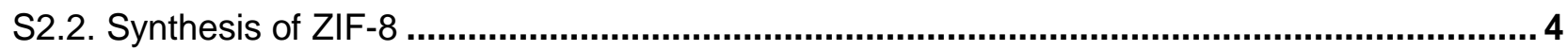

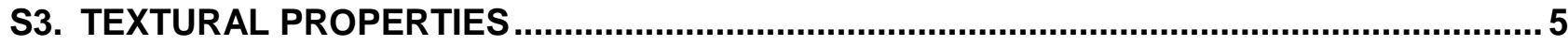

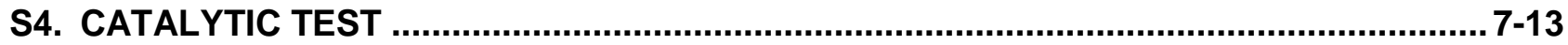

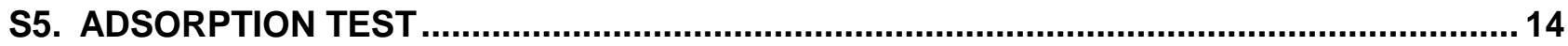

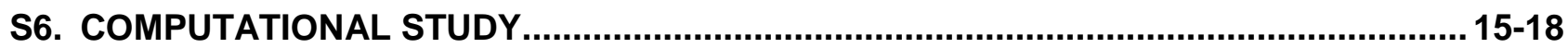

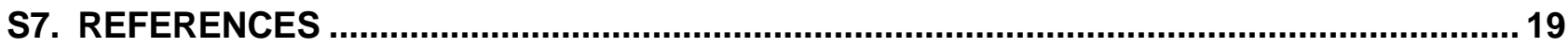


S1. GENERAL CONSIDERATIONS: STARTING MATERIALS AND CHARACTERIZATION

\section{S1.1. Materials and reagents}

All the general reagents and solvents were commercially available and used as received. $\mathrm{Zn}(\mathrm{OAc})_{2} \cdot 2 \mathrm{H}_{2} \mathrm{O}$, 2-methylimidazole (H-MelM), $N, N^{\prime}$-dimethylformamide (DMF), 4-chloropyridine hydrochloride, morpholine and acetonitrile were purchased from Sigma-Aldrich. The 1,4-bis(1Hpyrazol-4-yl)benzene $\left(\mathrm{H}_{2} \mathrm{BDP}\right)$ ligand was prepared as previously described in the literature. ${ }^{[1]}$ The 4-chloropyridine free base was prepared from 4-chloropyridine hydrochloride and a sodium hydrogen carbonate solution, as described in literature. ${ }^{[2]}$

\section{S1.2. Physical and chemical characterization}

PXRD patterns of the ZnBDP and ZIF-8 were collected in a PANalytical X'Pert PRO diffractometer using copper radiation $\left(\mathrm{Cu} \mathrm{K}_{\alpha}\right)$ with an $\mathrm{X}^{\prime}$ Celerator detector, operating at $40 \mathrm{~mA}$ and $45 \mathrm{kV}$. Profiles were collected in the $2^{\circ}<2 \theta<90^{\circ}$ range with a step size of 0.013 .

\section{S1.3. Computational details}

The adsorption simulations were performed using Materials Studio (MS) 2017 R2 with the Adsorption locator module. This involves a Monte Carlo search of the configurational space of the sorbate-sorbent system while the temperature is slowly decreased. This module considers the framework rigid, to account for its flexibility we further refined the model and used the result as an input for a Molecular Dynamic (MD) simulation. MD simulations were performed by using the charges of the atoms obtained via Qeq calculations and the DREIDING force field, ${ }^{[3]}$ as implemented in the Forcite module at $343 \mathrm{~K}$ for $2 \mathrm{~ns}$ in which all the atoms were free to move in the NVT ensemble. Diffusion coefficients are obtained from the mean square displacement, generated by the trajectory of the $\mathrm{Cl}$-py with morpholine, $\mathrm{N}$-methylaniline and $\mathrm{N}$-phenylaniline molecules, respectively. 


\section{S2. SYNTHESIS}

Synthetic procedure of $\mathrm{ZnBDP}: \mathrm{H}_{2} \mathrm{BDP}(0.5 \mathrm{mmol})$ and $\mathrm{Zn}(\mathrm{OAc})_{2} \cdot 2 \mathrm{H}_{2} \mathrm{O}(0.5 \mathrm{mmol})$ were dissolved in DMF $(40 \mathrm{~mL})$ and heated to $150^{\circ} \mathrm{C}$. The mixture was allowed to react overnight under reflux. After being cooled to room temperature (RT), the solid was collected by centrifugation (3000 rpm, $10 \mathrm{~min})$ and washed with DMF $(2 \times 10 \mathrm{~mL})$ and ethanol $(2 \times 10 \mathrm{~mL})$. The solids were dried at $150^{\circ} \mathrm{C}$ for $12 \mathrm{~h}$ under vacuum. ${ }^{[4]}$

Synthetic procedure of ZIF-8 with high micropore area (ZIF-8DMF): A solid mixture of zinc nitrate hexahydrate $(0.8 \mathrm{mmol})$ and 2-methylimidazole $(\mathrm{H}-\mathrm{MeIM})(0.7 \mathrm{mmol})$ was dissolved in $18 \mathrm{ml}$ of DMF. The bottle with the solution was heated at $140^{\circ} \mathrm{C}$ for $24 \mathrm{~h}$. After removal of mother liquor from the mixture, chloroform $(20 \mathrm{ml})$ was added. Colorless polyhedral crystals were collected from the upper layer, washed with DMF, and dried in air. Before gas-sorption analysis, ZIF-8 sample was immersed in methanol at ambient temperature for $48 \mathrm{~h}$ and evacuated at ambient temperature for $5 \mathrm{~h}$, then at $200^{\circ} \mathrm{C}$ for $2 \mathrm{~h}$. ${ }^{[5]}$

Synthetic procedure of ZIF-8 with high external surface area (ZIF-8EtOH): zinc nitrate hexahydrate $(2 \mathrm{mmol})$ and $\mathrm{Hmim}(4 \mathrm{mmol})$ were dissolved in $3 \mathrm{~mL}$ of deionized water. $10 \mathrm{mmol}$ of trimethylamine was added after that zinc nitrate and 2-methylimidazole solutions were mixed together. The solution quickly turned into milk-like suspension, and stirred for $10 \mathrm{~min}$ at room temperature to complete the crystallization. The product was collected by centrifugation (3000 rpm, $10 \mathrm{~min}$ ), washed with deionized water three times and dried at $60 \stackrel{\circ}{\mathrm{C}}$ overnight. [6] 
S3. $\quad \mathrm{N}_{2}$ PHYSISORPTION AND THERMOGRAVIMETRIC ANALYSIS
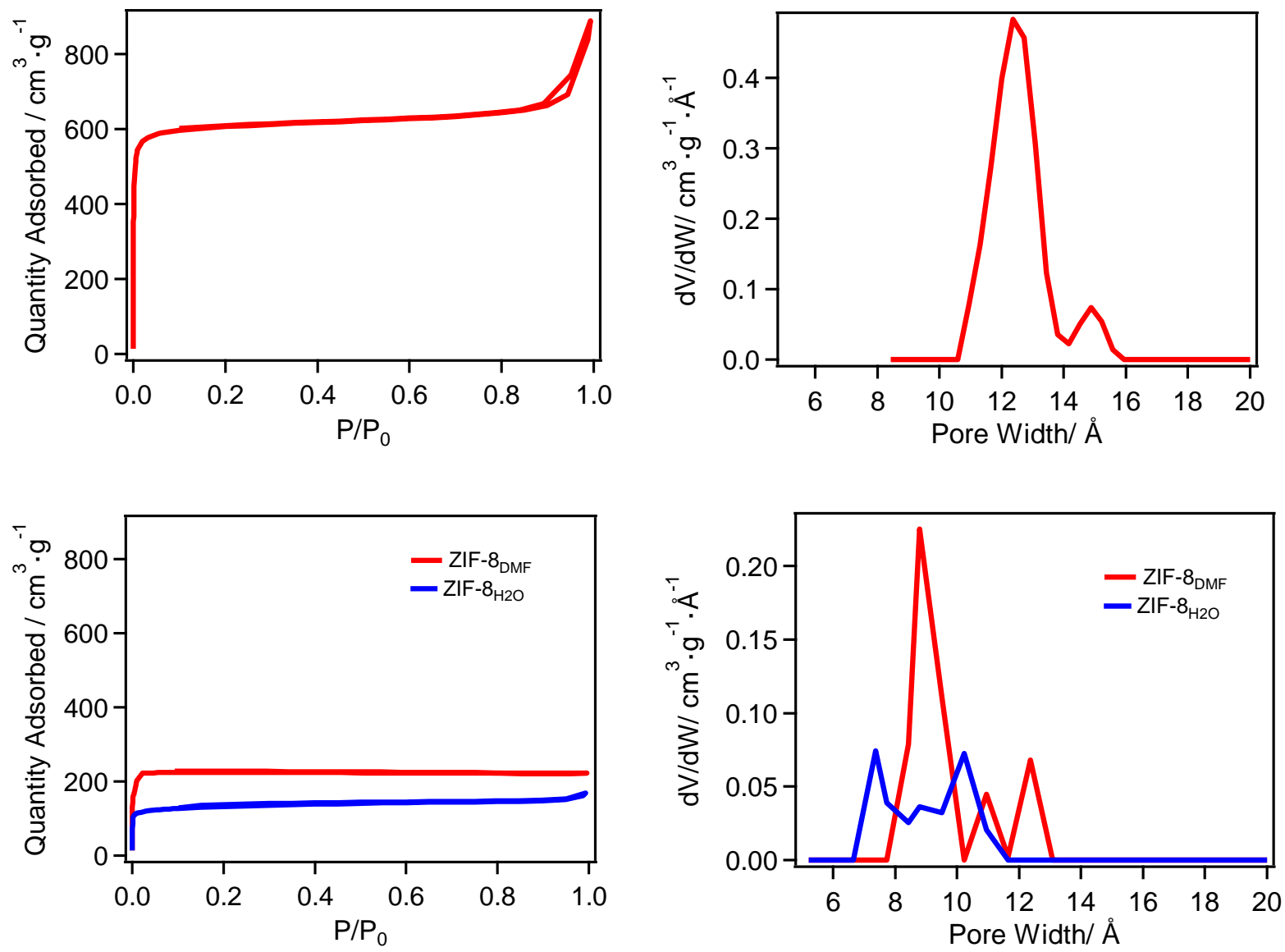

Figure S1. Nitrogen physisorption isotherms (left) and pore size distributions (right) of ZnBDP (top) and ZIF-8 (bottom) prepared by the two different methods described above.

Table S1. Textural properties of the $\mathrm{Zn}$ reticular catalysts

\begin{tabular}{|c|c|c|c|c|}
\hline Sample & BET area $\left(\mathbf{m}^{\mathbf{2}} \cdot \mathbf{g}^{-1}\right)$ & $\begin{array}{c}\text { Micropore } \\
\text { area }\left(\mathbf{m}^{\mathbf{2}} \cdot \mathbf{g}^{-1}\right)\end{array}$ & $\begin{array}{c}\text { External surface } \\
\text { area }\left(\mathbf{m}^{\mathbf{2}} \cdot \mathbf{g}^{-1}\right)\end{array}$ & $\begin{array}{c}\text { V } \text { Pore } \\
\left(\mathbf{c m}^{\mathbf{3}} \cdot \mathbf{g}^{-\mathbf{1}}\right)\end{array}$ \\
\hline ZIF-8DMF & 1030 & 1029 & 1 & 0.35 \\
\hline ZIF-8H2O & 508 & 391 & 117 & 0.15 \\
\hline ZnBDP & 1943 & 1730 & 213 & 0.85 \\
\hline
\end{tabular}



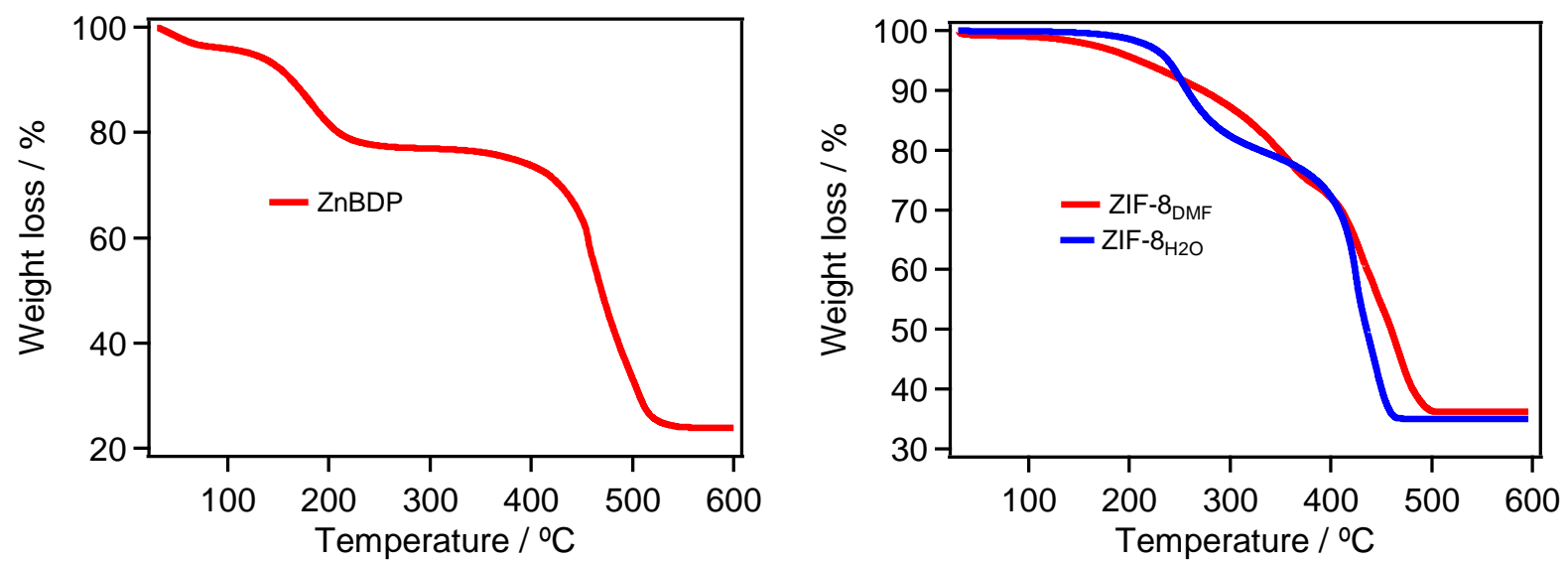

Figure S2. TGA of ZnBDP (left) and ZIF-8 (right) prepared by the two different methods described above.

Table S2. Missing linker defects in the $\mathrm{Zn}$ reticular catalysts

\begin{tabular}{|c|c|c|c|c|}
\hline Sample & $\begin{array}{c}\text { Linker } \\
\text { (\% wt.) }\end{array}$ & $\begin{array}{c}\text { ZnO } \\
\text { (\% wt.) }\end{array}$ & $\begin{array}{c}\text { Linker/Zn experimental } \\
\text { (mol/mol) }\end{array}$ & $\begin{array}{c}\text { Linker/Zn expected } \\
\text { (mol/mol) }\end{array}$ \\
\hline ZIF-8DMF & 50 & 36 & 1.7 & 2 \\
\hline ZIF-8H2O & 47 & 35 & 1.6 & 2 \\
\hline ZnBDP & 55 & 23 & 0.9 & 1 \\
\hline
\end{tabular}




\section{S3. CATALYTIC TESTS}

$10 \mathrm{mg}(90 \mu \mathrm{mol})$ of 4 -chloropyridine and $10 \mu \mathrm{L}$ of morpholine in $0.5 \mathrm{~mL}$ of acetonitrile were added to $10 \mathrm{mg}$ of $\mathrm{Zn}\left(\mathrm{NO}_{3}\right)_{2} \cdot 9 \mathrm{H}_{2} \mathrm{O}$ (50 $\mu \mathrm{mol} \mathrm{Zn}$ ) (for the homogeneous catalytic test) or ZIF-8 (40 $\mu \mathrm{mol} \mathrm{Zn}), \mathrm{ZnBDP}(20 \mu \mathrm{mol} Z \mathrm{Zn})$. The reaction was stirred at $70^{\circ} \mathrm{C}$ in a glass vial for 3 days and sample aliquots were analysed by GC-FID (Gas Chromatography-Flame Ionization Detector) and ${ }^{1} \mathrm{H}$ NMR (see Fig. S3 and S4). Both the $\mathrm{GC}$ yield $(77 \%)$ and ${ }^{1} \mathrm{H}$ NMR yield $(78 \%)$ using $\mathrm{Zn}\left(\mathrm{NO}_{3}\right)_{2}$ as catalyst after $72 \mathrm{~h}$ are similar.

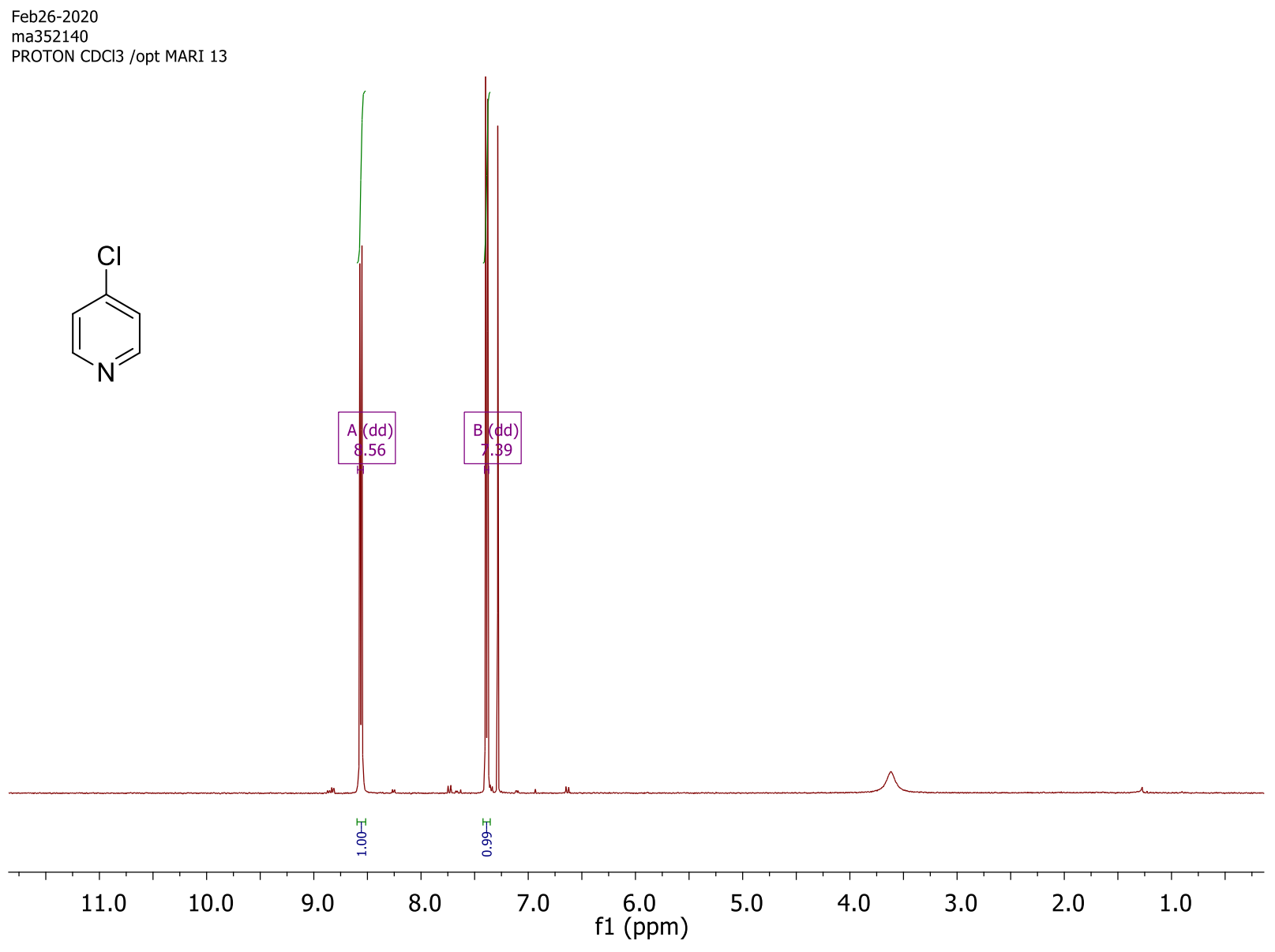

Figure S3. ${ }^{1} \mathrm{H}$ NMR $\left(300 \mathrm{MHz}, \mathrm{CDCl}_{3}\right)$ of the 4-chloropyridine free base: $\delta 8.56$ (dd, $J=$ 4.6, $1.5 \mathrm{~Hz}, 2 \mathrm{H}$ ), 7.39 (dd, $J=4.6,1.5 \mathrm{~Hz}, 2 \mathrm{H}$ ). 
<smiles>c1cc(N2CCOCC2)ccn1</smiles><smiles>C=CC(C)CC</smiles>
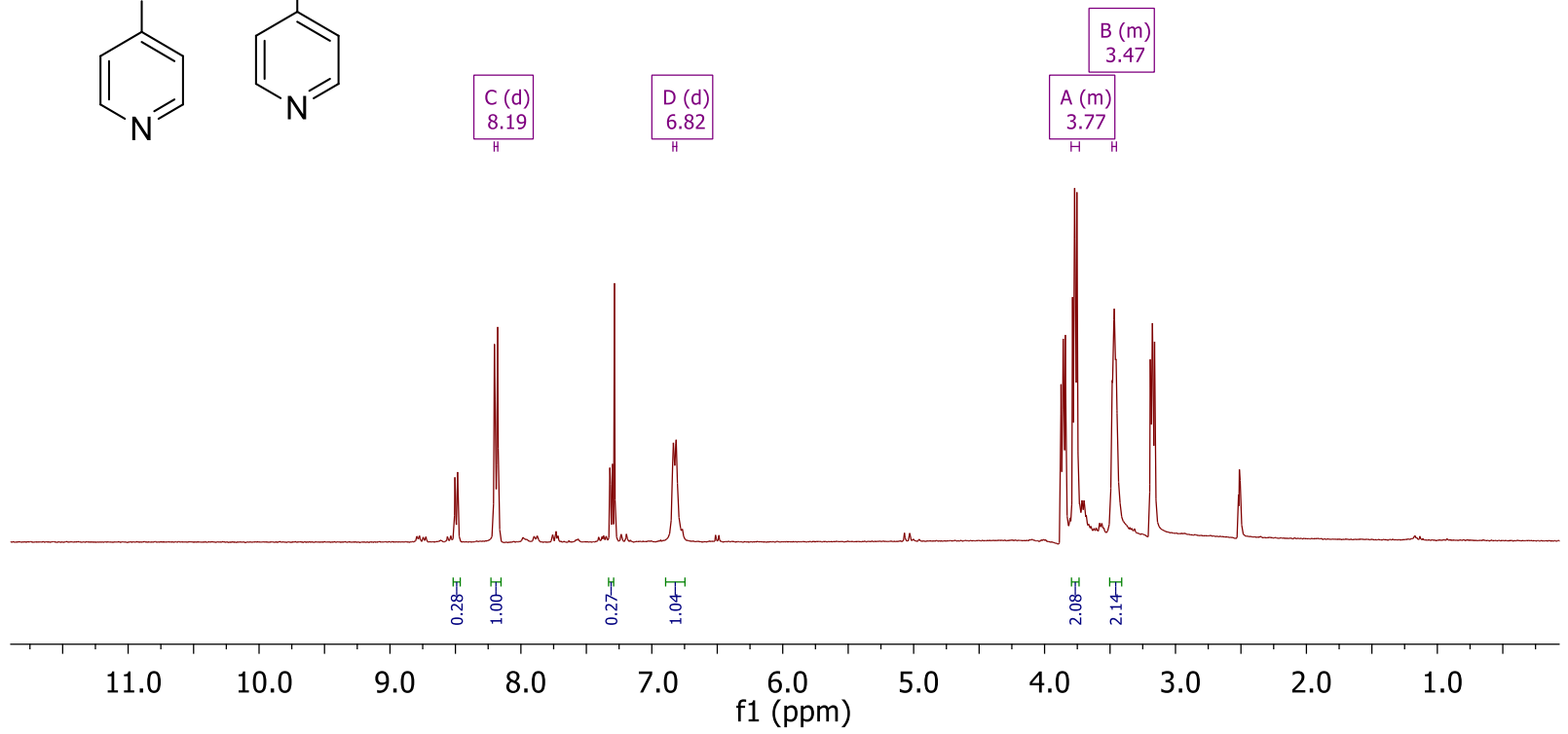

Figure S4. ${ }^{1} \mathrm{H}$ NMR $\left(300 \mathrm{MHz}, \mathrm{CDCl}_{3}\right)$ of the reaction between 4-chloropyridine and morpholine using $\mathrm{Zn}\left(\mathrm{NO}_{3}\right)_{2}$ as catalyst after $72 \mathrm{~h}$ : $\delta 8.19(\mathrm{~d}, J=7.4 \mathrm{~Hz}, 2 \mathrm{H}), 6.82(\mathrm{~d}, J=$ $6.5 \mathrm{~Hz}, 2 \mathrm{H}), 3.80-3.73(\mathrm{~m}, 4 \mathrm{H}), 3.48-3.45(\mathrm{~m}, 4 \mathrm{H})$. 


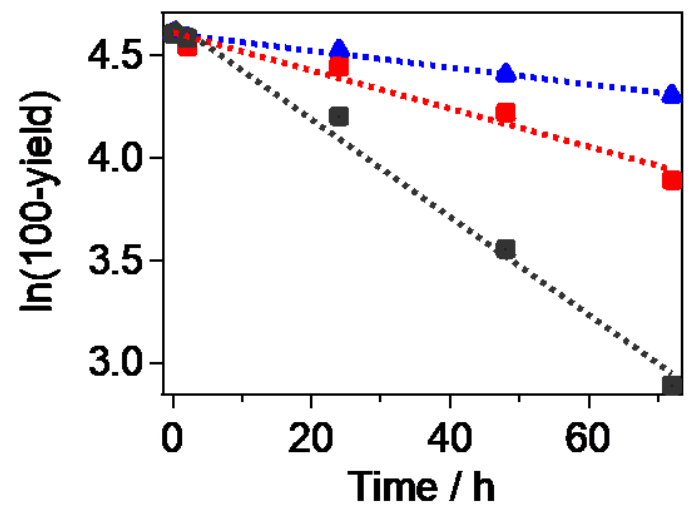

Figure S5. Kinetic fit to pseudo-first order reaction of 4-chloropyridine with morpholine in the presence of $\mathrm{Zn}\left(\mathrm{NO}_{3}\right)_{2}$ (black), $\mathrm{ZIF}-8$ (blue) or $\mathrm{ZnBDP}$ (red).

The equations of the fit are presented below, being $y=\ln (100$-yield $)$ and $t$ the time:

$$
\begin{aligned}
& \mathrm{Zn}\left(\mathrm{NO}_{3}\right)_{2}: y=(4.66 \pm 0.06) \cdot t-(0.024 \pm 0.001), R^{2}=0.987 \\
& Z I F-8: y=(4.604 \pm 0.008) \cdot t-(0.0041 \pm 0.0002), R^{2}=0.992 \\
& Z n B D P: y=(4.61 \pm 0.04) \cdot t-(0.009 \pm 0.001), R^{2}=0.957
\end{aligned}
$$

For the recycling test, the used ZnBDP catalyst during $72 \mathrm{~h}$ was isolated from the reaction mixture by centrifugation (3000 rpm, $10 \mathrm{~min}$ ) and washed with ethanol. The recovered catalyst was dried and reused under the same reaction conditions. For the hot filtration test, the used catalyst was isolated from the reaction mixture by centrifugation (3000 rpm, $10 \mathrm{~min}$ ) and the reaction was followed without the catalyst under the same conditions. 

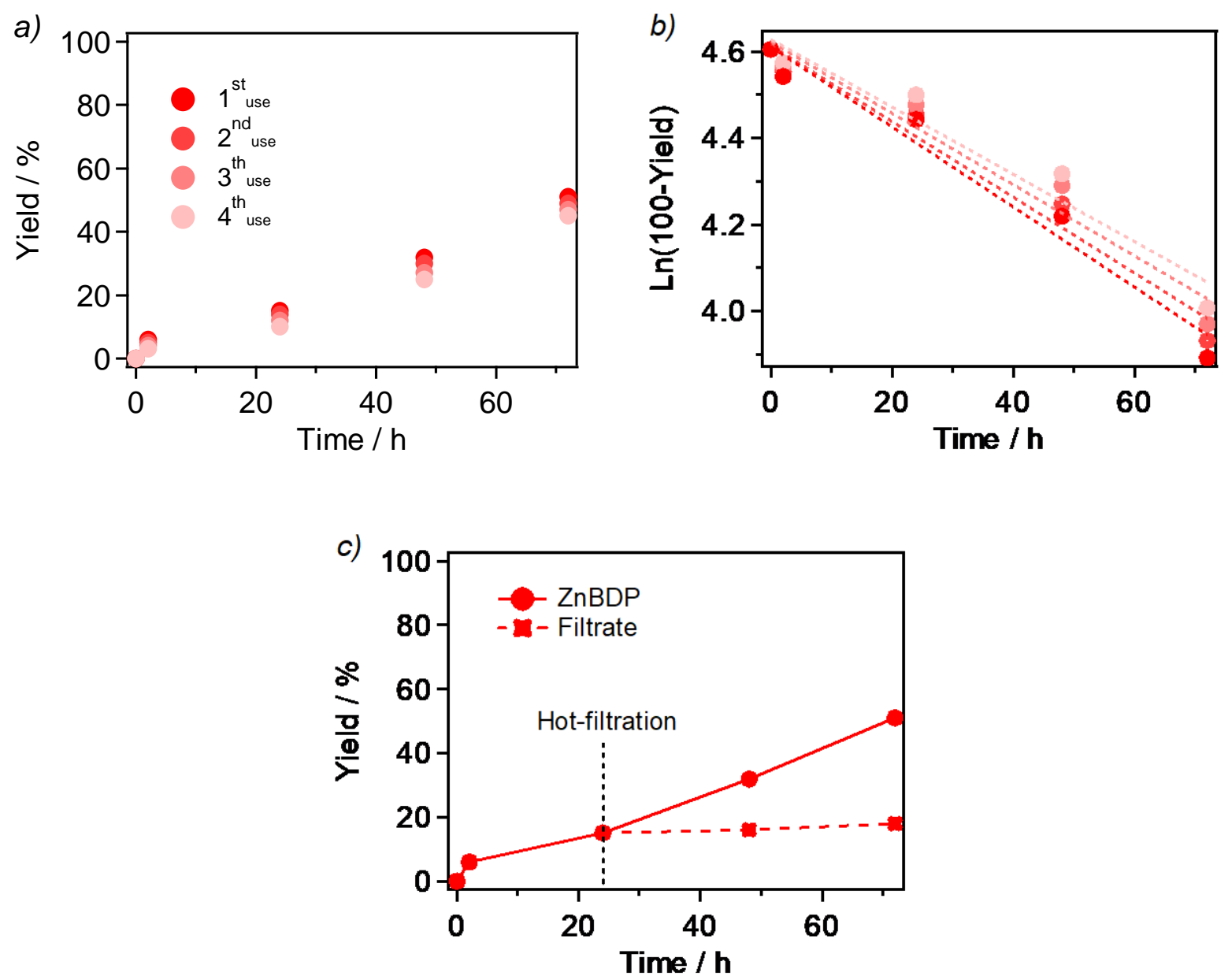

Figure S6. Reuse of ZnBDP in four reaction cycles (a), linear fit for the obtention of the kinetic rate constants (b) and leaching test by hot filtration of the MOF catalyst (c). The equations of the fit are presented below.

$$
\begin{aligned}
& \operatorname{Ln}(100-\text { Yield }) \text { cycle } 1=-9.3 \cdot 10^{-3} \cdot t+4.61 ; R^{2}=0.968 \\
& \operatorname{Ln}(100-\text { Yield }) \text { cycle2 }=-8.8 \cdot 10^{-3} \cdot t+4.61 ; R^{2}=0.967 \\
& \operatorname{Ln}(100-\text { Yield }) \text { cycle3 }=-8.2 \cdot 10^{-3} \cdot t+4.62 ; R^{2}=0.954 \\
& \operatorname{Ln}(100-\text { Yield }) \text { cycle4 }=-7.8 \cdot 10^{-3} \cdot t+4.62 ; R^{2}=0.947
\end{aligned}
$$



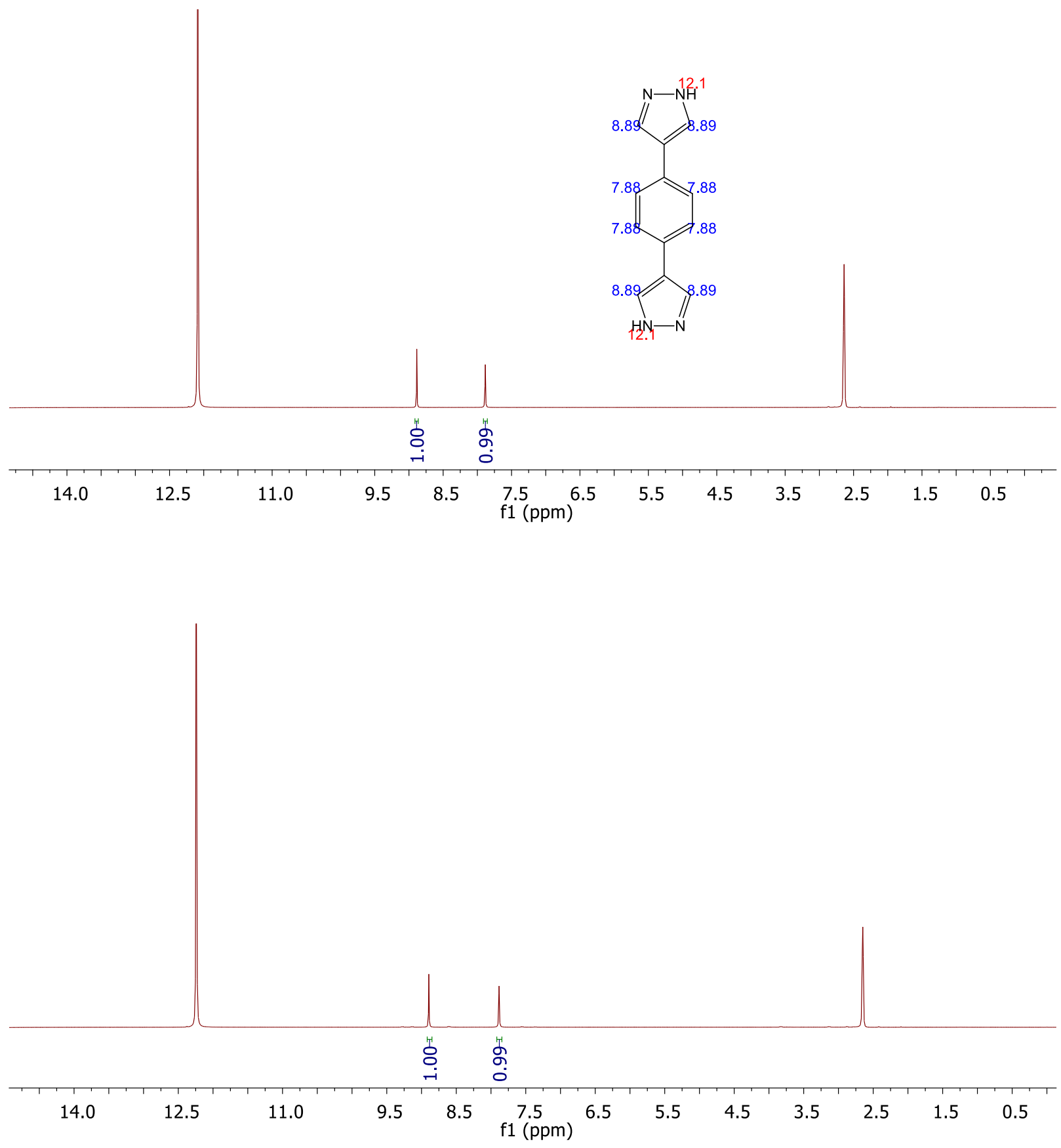

Figure S7. ${ }^{1} \mathrm{H}$ NMR (300 MHz, DMSO) of the ZnBDP before (top) and after the catalytic cycle (b), upon digestion of $5 \mathrm{mg}$ of MOF in $0.7 \mathrm{ml}$ DMSO-d and $0.1 \mathrm{ml} \mathrm{H}_{2} \mathrm{SO}_{4}-\mathrm{d}$. Top spectra: $\delta 12.09$ (s, 2H), $8.89(\mathrm{~s}, 4 \mathrm{H}), 7.88(\mathrm{~s}, 4 \mathrm{H})$. Bottom spectra: $\delta 12.24(\mathrm{~s}, 2 \mathrm{H}), 8.89$ (s, 4H), $7.88(\mathrm{~s}, 4 \mathrm{H})$. 


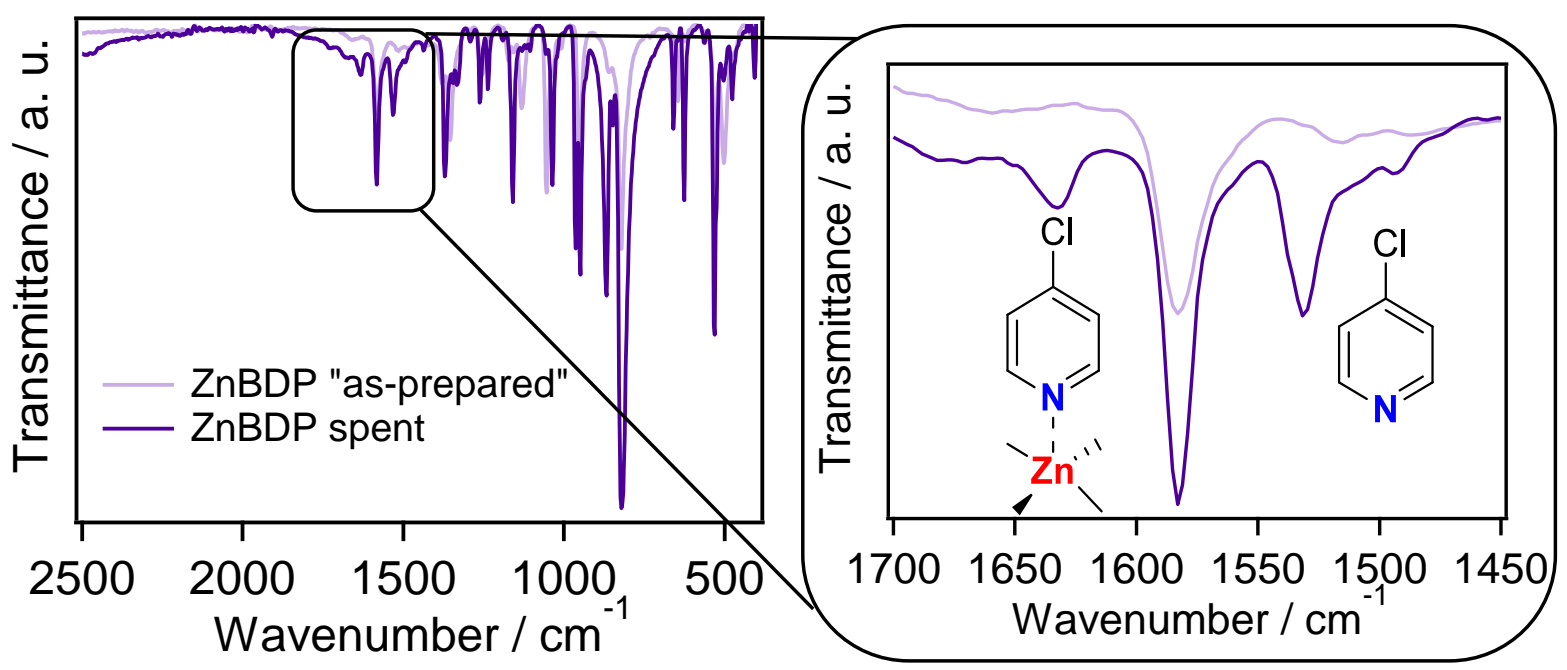

Figure S8. Left: FTIR of the ZnBDP before and after $24 \mathrm{~h}$ of reaction between 4chloropyridine and morpholine under the conditions described in section S3. The material was washed with fresh $\mathrm{CH}_{3} \mathrm{CN}$ and dried overnight under ambient conditions. before the measurement. Right: interaction between the $\mathrm{N}$ atom of pyridine and the $\mathrm{Zn}$ sites of the MOF.

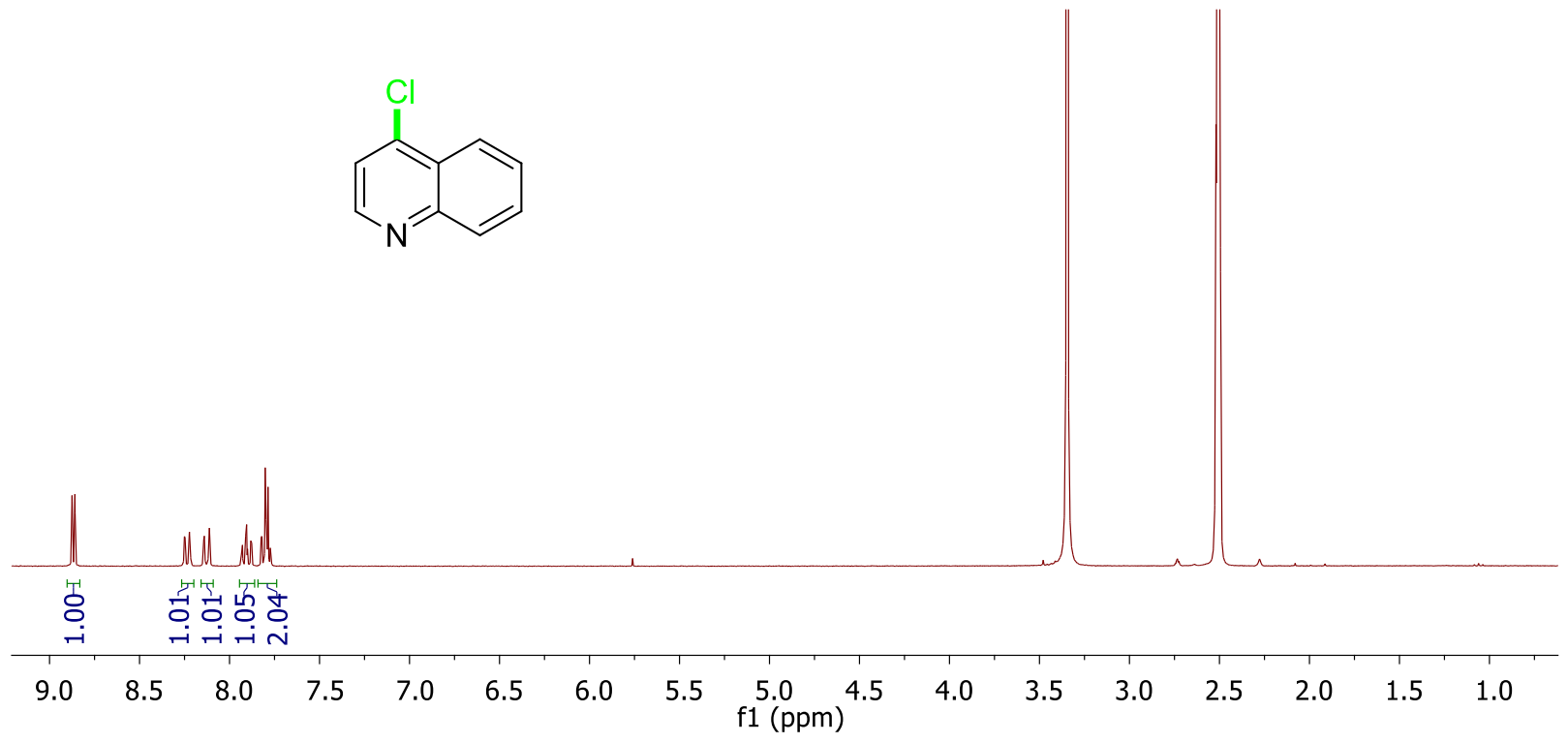




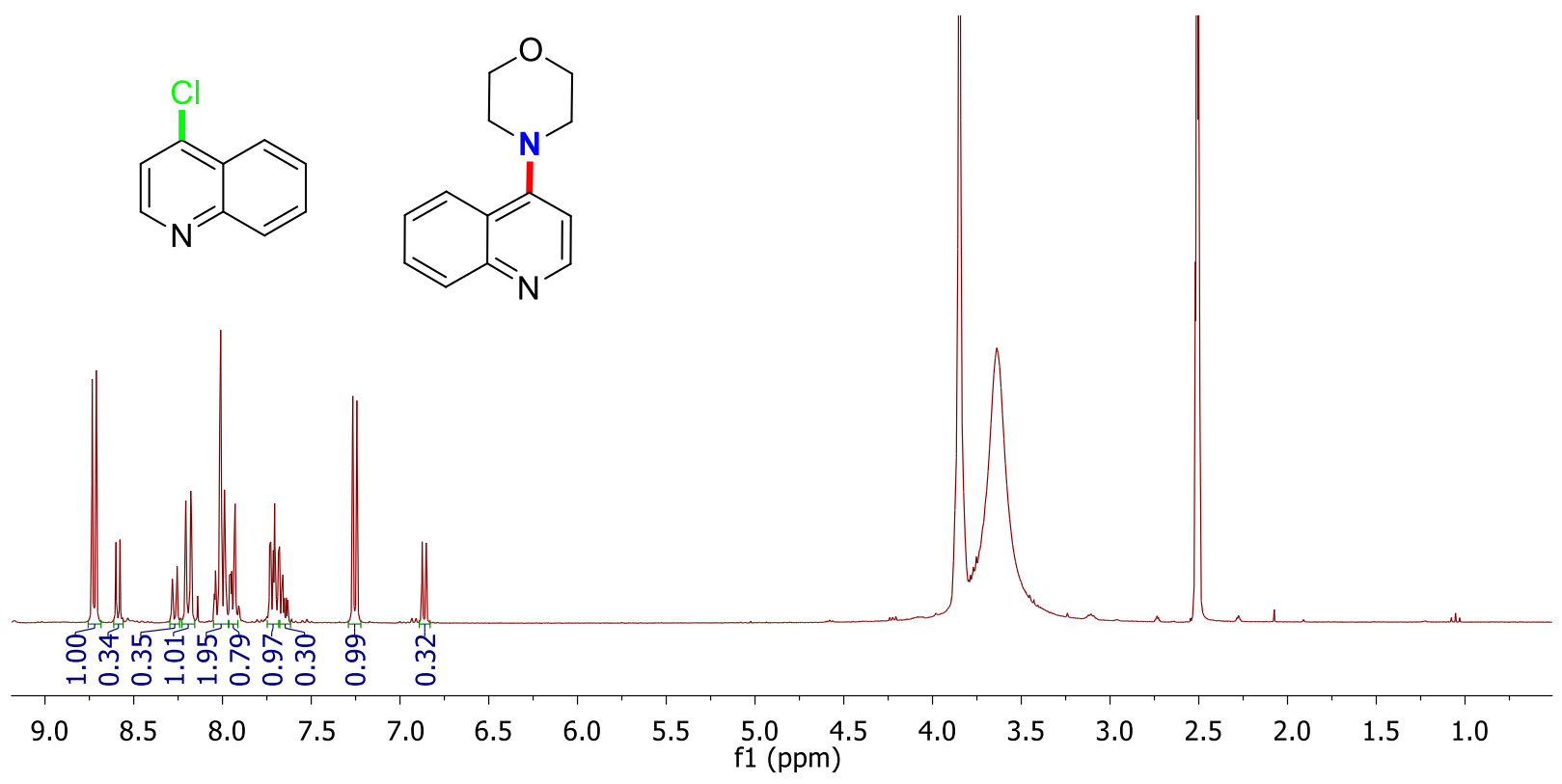

Figure S9. ${ }^{1} \mathrm{H}$ NMR (300 MHz, DMSO) of the reaction between 4-chloroquinoline (see top spectra for the pure reagent) and morpholine using ZnBDP as catalyst after $24 \mathrm{~h}$ (same conditions as for 4-chloropyridine). The peaks corresponding to the animated product $(25 \%$ yield) are: $\delta 8.58(\mathrm{t}, \mathrm{J}=5.4 \mathrm{~Hz}, 1 \mathrm{H}), 8.30-8.23(\mathrm{~m}, 1 \mathrm{H}), 7.97-7.90(\mathrm{~m}$, $2 \mathrm{H}), 7.67-7.62(\mathrm{~m}, 1 \mathrm{H}), 6.86(\mathrm{~d}, \mathrm{~J}=6.9 \mathrm{~Hz}, 1 \mathrm{H}), 3.85(\mathrm{~d}, \mathrm{~J}=1.0 \mathrm{~Hz}, 4 \mathrm{H})$.

Table S3. Conversion of 4-chloropyridine $(90 \mu \mathrm{mol})$ by reaction with secondary amines $(120 \mu \mathrm{mol})$ after $72 \mathrm{~h}$ on ZIF-8 $(40 \mu \mathrm{mol} \mathrm{Zn})$ or ZnBDP $(20 \mu \mathrm{mol} \mathrm{Zn})$ in $0.5 \mathrm{~mL}$ of acetonitrile. The reaction was stirred at $70^{\circ} \mathrm{C}$ in a glass vial for 3 days and sample aliquots were analyzed by GC-FID.

\begin{tabular}{cccc}
\hline Substrate & Size/ $\AA$ & ZnBDPa $^{a}$ & ZIF-8 $^{\mathbf{a}}$ \\
\hline Morpholine & 4.9 & $51 \%(2.3)$ & $26 \%(0.6)$ \\
\hline Methylaniline & 6.7 & $98 \%(4.5)$ & $51 \%(1.2)$ \\
\hline Phenylaniline & 11.9 & $50 \%(2.3)$ & $17 \%(0.4)$
\end{tabular}

${ }^{a}$ Conversion and (TONzn) 


\section{S4. CHLOROPYRIDINE ADSORPTION TESTS}

First, we perform a GC Calibration using 5, 10, 15 and $20 \mu \mathrm{L}$ of 4-chloropyridine in $5 \mathrm{~mL}$ of acetonitrile. The $A_{4-C l p y} / A_{C H 3 C N}$ is taken as the actual concentration of 4chloropyridine in $\mathrm{g} / \mathrm{L}$.

The experiments related to the adsorption of 4-Chloropyridine on the ZnBDP porous solid was carried out in the following way: A solution of $10 \mathrm{mg}(90 \mu \mathrm{mol})$ of 4 chloropyridine in $4 \mathrm{~mL}$ of acetonitrile, [4-Clpy $]_{0}=2.5 \mathrm{mg} / \mathrm{mL}$, was added to $10 \mathrm{mg}$ of the porous solid, i.e. ZIF-8 (40 $\mu \mathrm{mol} Z \mathrm{Zn}$ ) or ZnBDP (20 $\mu \mathrm{mol} \mathrm{Zn}$ ), in a glass vial. The mixture was stirred $(300 \mathrm{rpm})$ at $70^{\circ} \mathrm{C}$ overnight. After this time, the liquid supernatant was isolated by centrifugation (3000 rpm, $5 \mathrm{~min}$ ) and the 4-Chloropyridine, [4-Clpy]1day, was analysed by GC-FID. The amount of 4-Clpy adsorbed in the porous solid was calculated taking into account the initial [4-Clpy]o, according to:

4-Clpy uptake $=[4-$ Clpy $] 0-[4-\text { Clpy }]_{1 \text { day }}$

where [4-Clpy]o and [4-Clpy] 1day is the detected GC signal for the initial and equilibrium solution, respectively.

Table S4. Experimental adsorption of 4-chloropyridine on ZIF-8 or ZnBDP.

\begin{tabular}{ccccc}
\hline Sample & \% uptake & gclpy/gMOF & mmolclpy/gMOF & molclpy/molmoF \\
\hline ZIF-8 & 13 & 0.13 & 1.17 & 0.29 \\
\hline ZnBDP & 23 & 0.23 & 2.03 & 1.01
\end{tabular}


S5. COMPUTATIONAL STUDY
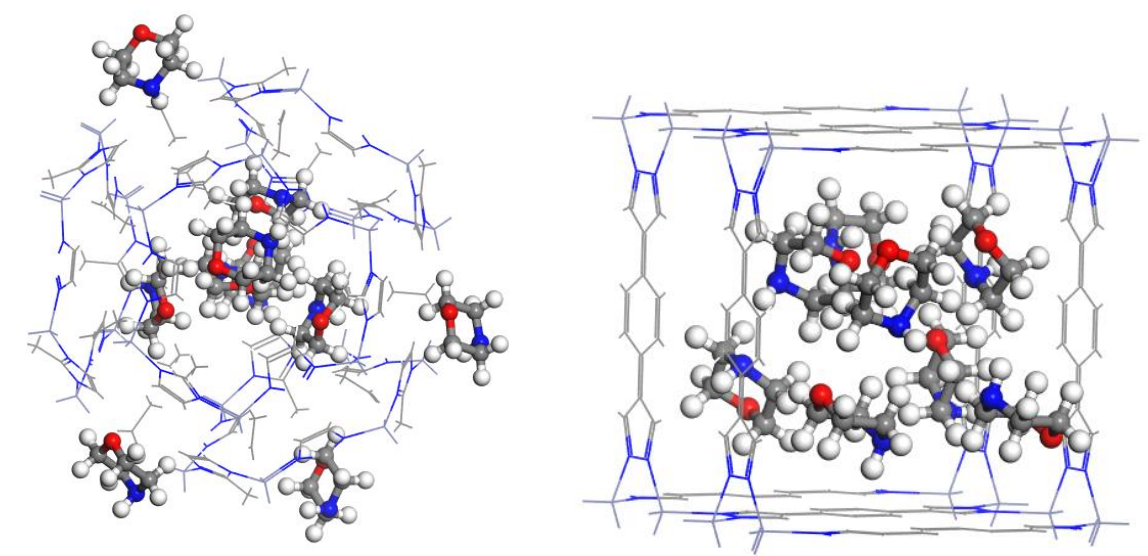

Figure S10. Docking of 6 and 8 molecules of morpholine on ZIF-8 (left) or ZnBDP (right) using the Adsorption locator module (MC) of Material Studio computer program.
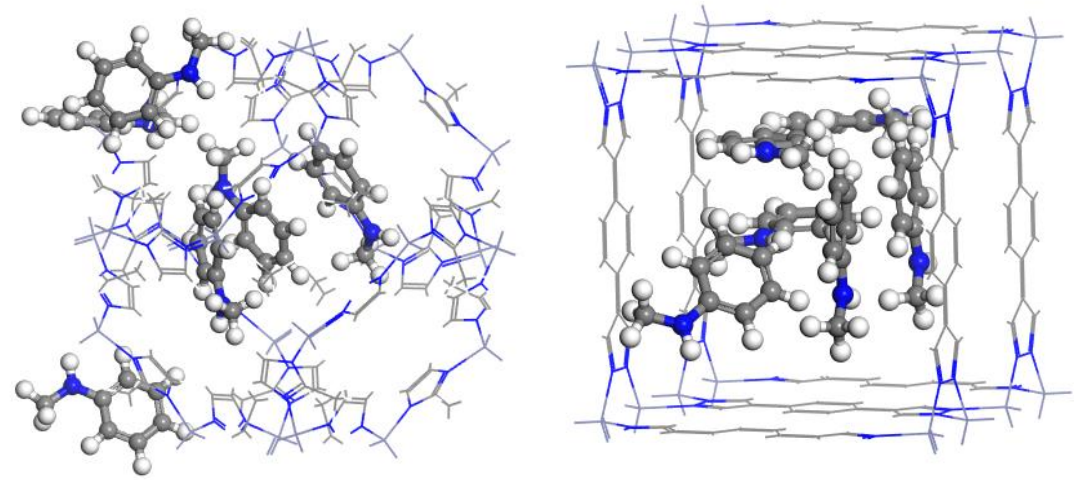

Figure S11. Docking of 3 and 6 molecules of N-methyl aniline on ZIF-8 (left) or ZnBDP (right) using the Adsorption locator module (MC).
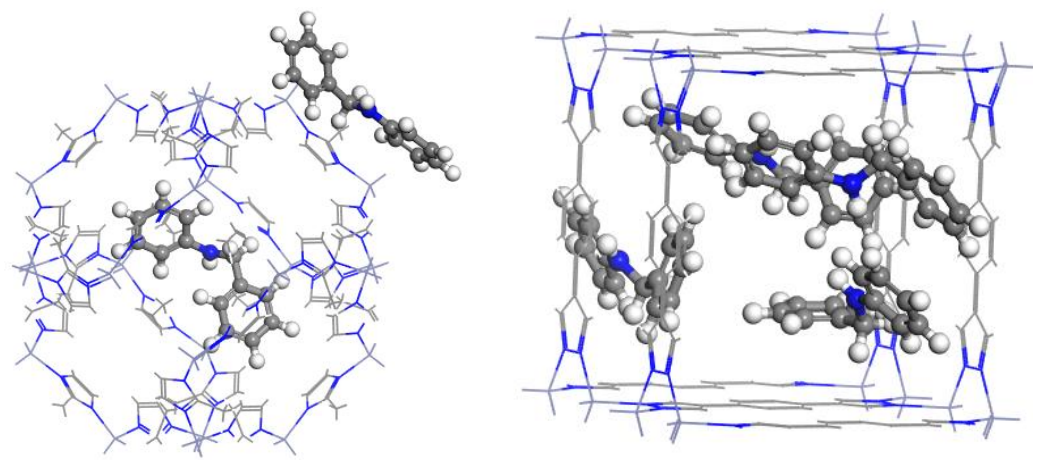

Figure S12. Docking of 1 and 4 molecules of N-phenyl aniline on ZIF-8 (left) or ZnBDP (right) using the Adsorption locator module (MC) of Material Studio computer program. 

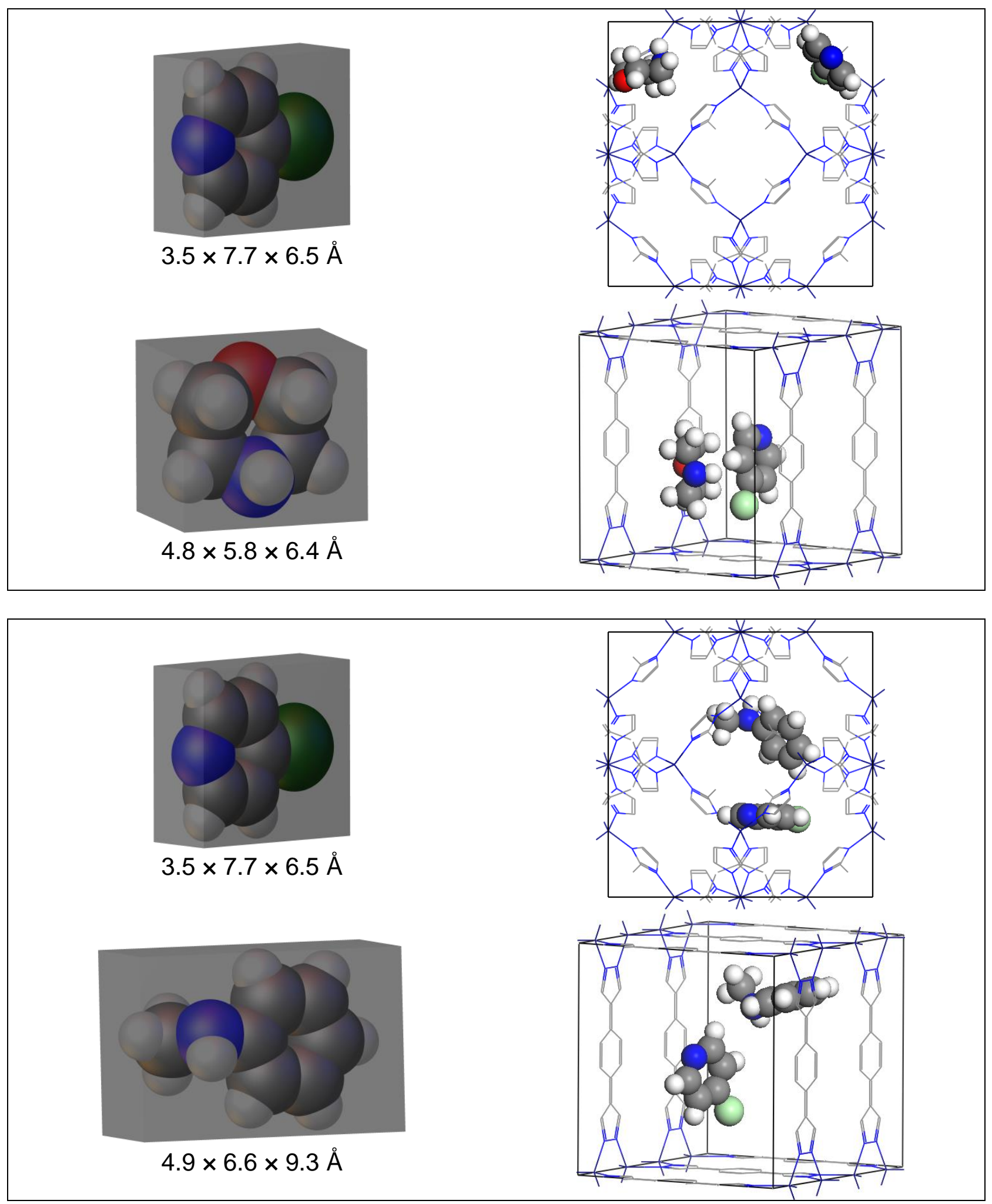


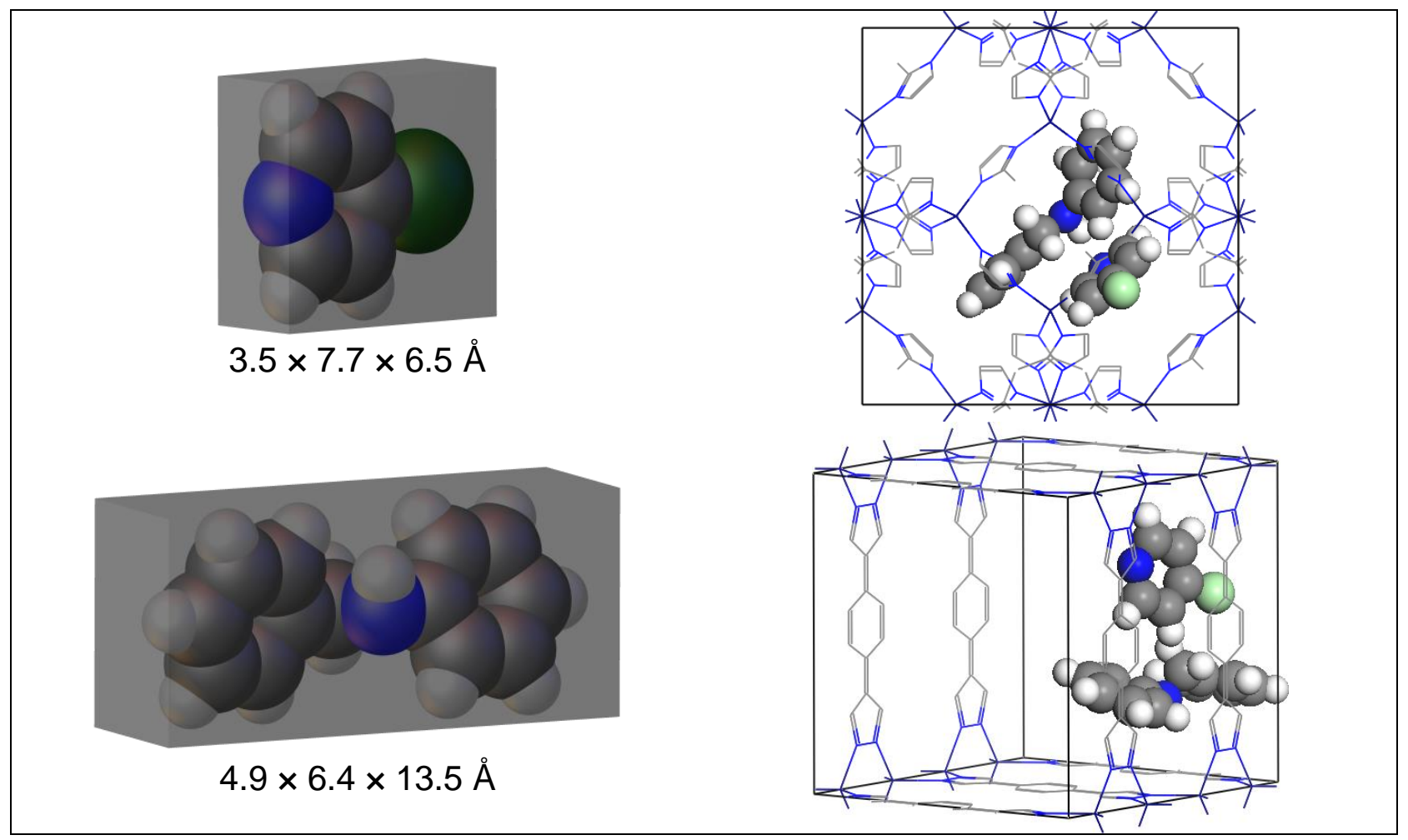

Figure S13. Molecular dimensions of 4-chloropyridine and the secondary amines: morpholine, $\mathrm{N}$-methylaniline and $\mathrm{N}$-phenylaniline, together with their adsorption sites in ZIF-8 or ZnBDP.

Table S5. Self-diffusivity coefficient $\left(D_{\text {Amine }}\right.$ in $\left.\mathrm{cm}^{2} / \mathrm{s}\right)$ of 4-chloropyridine and the secondary amines: morpholine, $\mathrm{N}$-methylaniline and $\mathrm{N}$-phenylaniline.

\begin{tabular}{ccccccc}
\hline & Cl-py & morpholine & Cl-py & N-methylaniline & Cl-py & N-phenylaniline \\
\hline ZIF-8 & $1.2 \mathrm{E}-07$ & $1.0 \mathrm{E}-07$ & $2.7 \mathrm{E}-07$ & $2.3 \mathrm{E}-07$ & $1.7 \mathrm{E}-07$ & $9.3 \mathrm{E}-08$ \\
ZnBDP & $2.5 \mathrm{E}-05$ & $2.0 \mathrm{E}-05$ & $1.3 \mathrm{E}-06$ & $1.2 \mathrm{E}-04$ & $9.7 \mathrm{E}-07$ & $3.5 \mathrm{E}-05$ \\
& & & & &
\end{tabular}




\section{Computational Methods for DFT.}

Periodic DFT calculations were performed with the were performed using the Vienna Ab initio Simulation Package (VASP). ${ }^{[7,8]}$ The electron-ion interactions were described using the projector-augmented-wave (PAW) formalism. ${ }^{[9]}$ For the geometry optimizations, we used the generalized gradient approximation (GGA) with the PerdewBurke-Ernzerhof (PBE) functional, ${ }^{[10]}$ and including van der Waals (vdW) corrections via the DFT-D3 method of Grimme. ${ }^{[11,12]}$ The kinetic energy cut-off for the plane-wave basis set expansion was chosen as $500 \mathrm{eV}$, and a $\Gamma$-points was used. The energies were calculated as $E_{A D S}=E_{(M O L+M O F)}-E_{M O F}-E_{M O L}$, where $E_{(M O L+M O F)}$ is the energy of $(1 \times 1 \times 2)$ cell of ZnBDP with the reactants molecules adsorbed, $E_{\text {MOF }}$ is the energy of the $(1 \times 1 \times 2)$ cell of $\mathrm{ZnBDP}$ and $\mathrm{EMOL}_{\mathrm{MO}}$ is the energy of reactants in the gas phase.
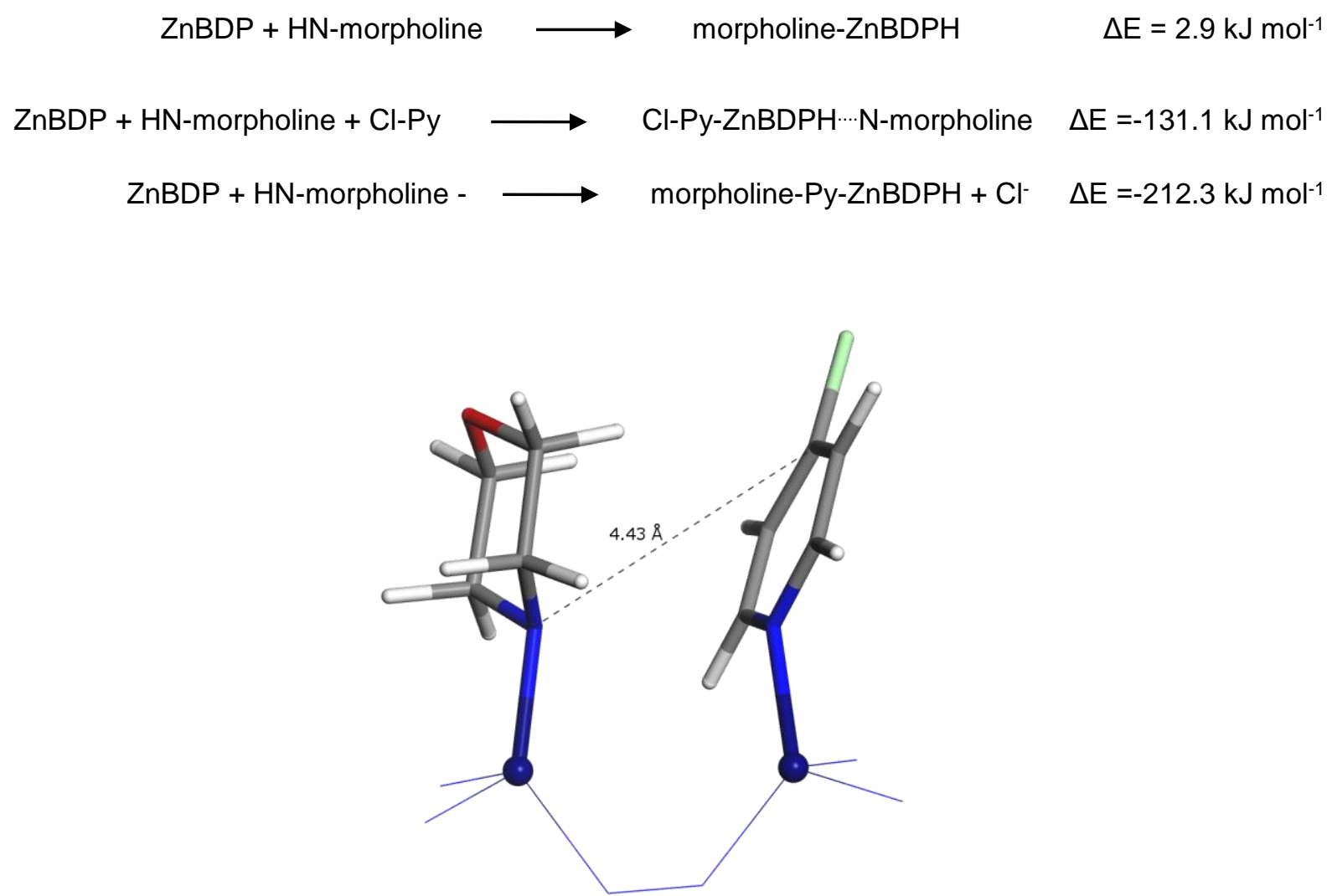

Figure S14. Interaction of morpholine and Cl-Py molecules with the two defective $\mathrm{Zn}$ atoms. 
S6. REFERENCES

[1] A. Maspero, S. Galli, N. Masciocchi, G. Palmisano, Chem. Lett. 2008, 37, 956957.

[2] S. Abou-Shehada, M. C. Teasdale, S. D. Bull, C. E. Wade, J. M. J. Williams, ChemSusChem 2015, 8, 1083-1087.

[3] S. L. Mayo, B. D. Olafson, W. A. Goddard III, J. Phys. Chem. 1990, 94, 88978909.

[4] S. Rojas, F. J. Carmona, C. R. Maldonado, P. Horcajada, T. Hidalgo, C. Serre, J. A. R. Navarro, E. Barea, Inorg. Chem. 2016, 55, 2650-2663.

[5] K. S. Park, Z. Ni, A. P. Côté, J. Y. Choi, R. Huang, F. J. Uribe-Romo, H. K. Chae, M. O'Keeffe, O. M. Yaghi, O. M. PNAS 2006, 104, 10186-10191.

[6] M. He, J. Yao, Q. Liu, K. Wang, F. Chen, H. Wang, Microporous Mesoporous Mater. 2014, 184, 55-60.

[7] G. Kresse, J. Furthmüller, Phys. Rev. B - Condens. Matter Mater. Phys. 1996, 54, 11169-11186.

[8] G. Kresse, J. Furthmüller, Comput. Mater. Sci. 1996, 6, 15-50.

[9] P. E. Blöchl, Phys. Rev. B 1994, 50, 17953-17979.

[10] J. P. Perdew, K. Burke, M. Ernzerhof, Phys. Rev. Lett. 1996, 77, 3865-3868.

[11] S. Grimme, J. Antony, S. Ehrlich, H. Krieg, J. Chem. Phys. 2010, 132, 154104.

[12] T. Bučko, J. Hafner, S. Lebègue, J. G. Ángyán, J. Phys. Chem. A 2010, 114, 11814-11824. 